\title{
Zinc Oxide as an Effective Mineral for Induced Moulting: Effects on Post Moult Performance of Laying Hens in the Humid Tropics
}

\author{
Ndubuisi Samuel Machebe ${ }^{1 *}$, Pamela Iweh ${ }^{1}$, Anselm Ego Onyimonyi ${ }^{1}$, Okezie Samuel Ekere $^{2}$ and Festus Abonyi ${ }^{3}$ \\ ${ }^{1}$ Department of Animal Science, University of Nigeria, Nsukka, Nigeria \\ ${ }^{2}$ Department of Veterinary Obstetrics and Reproductive Diseases, University of Nigeria, Nsukka, Nigeria \\ ${ }^{3}$ Department of Animal Health and Production, University of Nigeria, Nsukka, Nigeria
}

\begin{abstract}
The aim of this study was to evaluate the ability of using zinc oxide salts to induce moulting, and their effects on post moult performance and organ characteristics of laying hens. Two hundred ( 75 weeks of age) Isa Brown hens were randomly assigned to five Treatments ( $T$ ) groups of 40 hens, each namely; $T_{0}$-non-moulted hens and $T_{1}, T_{2}, T_{3}$, $\mathrm{T}_{4}$, representing moulted hens fed, respectively, $0.5 \%, 1.0 \%, 1.5 \%$ and $2.0 \%$ Zinc Oxide $(\mathrm{ZnO})$ supplementation per $\mathrm{kg}$ diet for 14 days. Organ evaluations of the hens were carried out 7 days post moult. Body weight loss and decline in feed intake of the birds were higher $(P<0.01)$ for moulted hens. Cessation of egg production occurred earlier $(P<0.05)$ in the same groups of birds. During post moult, the moulted hens exhibited greater $(P<0.01)$ percentage body weight gain, when compared with the non-moulted hens. Feed intake and hen-day egg production of birds on $1.0 \%, 1.5 \%$ and $2.0 \% \mathrm{ZnO}$ supplementation was higher $(\mathrm{P}<0.01)$, than those of other treatments. Feed conversion ratio was better $(\mathrm{P}<0.05)$ for the same groups of birds. Moulting with $\mathrm{ZnO}$ treatment influence highly $(\mathrm{P}<0.01)$ the number of days to resumption of egg production, with hens on $2.0 \% \mathrm{ZnO}$ resuming egg production much later than hens on $0.5 \%, 1.0 \%$, and $1.5 \% \mathrm{ZnO}$ treatments. The ovary, liver and kidney of the hens were affected $(\mathrm{P}<0.05)$ by the dietary $\mathrm{ZnO}$ contents. A greenish coloration of the liver was observed in hens fed $1.5 \%$ and $2 \% \mathrm{ZnO}$ supplementation. These results demonstrate that in order to achieve good post moult performance of laying hens in the humid tropics, farmers should practice the use of $1 \% \mathrm{ZnO}$ inclusion per $\mathrm{kg}$ diet, as an effective method to achieve induced moulting.
\end{abstract}

Keywords: Egg production; Organ; Forced moulting; Body weight

\section{Introduction}

The rate of increase in human population, especially in many developing countries already suffering from chronic hunger and malnutrition, demands that new strategies intended at guarantying food security in developing economies of the world is developed.

An effective means of ensuring rapid transformation in animal protein consumption and food security situation in developing countries is the application of various management strategies in poultry production, aimed at increasing the supply of meat and eggs to local communities faced with severe challenges of food insecurity. A method in poultry production designed to maximize egg production in laying hens is the practice of forced moulting. Force moulting, which is the practice of provoking complete flock of hens to moult simultaneously, aimed at extending egg production for more than one year [1], is not a common practice in many developing countries of the world. The practice has been extensively used as a management tool in many developed economies. The practice of force moulting completely halts reproductive function and precipitates a loss of feathers by the hen. However, egg production eventually resumes and increases rapidly to a profitable rate, following this artificial moult [2].

Several methods have been used by farmers to induce moult in laying hens. Among the various methods, feed removal or deprivation seems to be the most common method of practice by farmers. In recent years, however, the growing global concerns for animal rights and welfare have raised concerns over the practice of feed withdrawal, as a method of moulting [3]. For instance, researchers and public health authorities have identified the method as a significant risk factor for the infection of laying flocks with Salmonella enteritidis; the most important pathogen inside eggs, and known to be transmitted to humans [3]. Many researchers also subscribed that the practice of feed withdrawal is inhumane, and should be handled with upmost caution [4-6]. As an alternative to fasting laying hens as a method of inducing moult, several studies have advocated a non-feed withdrawal method, involving the manipulation of dietary minerals like sodium, calcium, iodine and zinc [6-8], etc. These alternative methods have been successfully used by scientist to induce moult in hens, and enhance the post moult egg production. Zinc is one of the several micronutrients that have attracted increased attention, because of their important role in maintaining health and nutrients condition. It is essential for physiologic and metabolic functions such as physical growth, immuno-competence, reproductive function, and neuron behavioral development [9]. Although abundant information exists in literature on the practical application of zinc salts as a means of achieving moulting in hen raised under temperate environment, there is a dearth of information on its application in the tropics, especially in most developing countries, where the method is uncommon. The study therefore was aimed at evaluating the effectiveness of using zinc oxide as a moulting agent for laying hens, on organ characteristics, and post moult production performance.

\section{Materials and Methods}

The study was conducted at the poultry unit of the Department of

*Corresponding author: Machebe Ndubuisi Samuel, Department of Animal Science, University of Nigeria, Nsukka, Nigeria, Tel: 234-8035487464; E-mail: ndubuisi.machebe@unn.edu.ng

Received December 11, 2012; Accepted January 17, 2013; Published January 19,2013

Citation: Machebe NS, Iweh P, Onyimonyi AE, Ekere OS, Abonyi F (2013) Zinc Oxide as an Effective Mineral for Induced Moulting: Effects on Post Moult Performance of Laying Hens in the Humid Tropics. J Veterinar Sci Technol S11: 003. doi:10.4172/2157-7579.S11-003

Copyright: (c) 2013 Machebe NS, et al. This is an open-access article distributed under the terms of the Creative Commons Attribution License, which permits unrestricted use, distribution, and reproduction in any medium, provided the original author and source are credited. 
Citation: Machebe NS, Iweh P, Onyimonyi AE, Ekere OS, Abonyi F (2013) Zinc Oxide as an Effective Mineral for Induced Moulting: Effects on Post Moult Performance of Laying Hens in the Humid Tropics. J Veterinar Sci Technol S11: 003. doi:10.4172/2157-7579.S11-003

Page 2 of 5

Animal Science Teaching and Research Farm, University of Nigeria Nsukka. The study lasted for a period of twelve (12) weeks. Two hundred (75 weeks of age) Isa Brown laying hens were randomly selected from the flock raised at the poultry unit of the Department of Animal Science, Teaching and Research Farm, University of Nigeria, Nsukka. The birds were housed one per cage and allowed 2 weeks for acclimation. During this period, birds were given vitamins supplementation, and were allowed full access to a formulated layer diet and water (Table 1). Egg production was also monitored to ensure that all hens were healthy and producing.

\begin{tabular}{|l|c|}
\hline Feed ingredients & Composition (\%) \\
\hline Maize & 48.00 \\
\hline Wheat offal & 12.00 \\
\hline Soya bean meal & 16.00 \\
\hline Palm kernel cake & 12.00 \\
\hline Fish meal & 2.00 \\
\hline Bone meal & 5.00 \\
\hline Limestone & 4.00 \\
\hline Lysine & 0.25 \\
\hline Methionine & 0.25 \\
\hline Vitamin Mineral Premix & 0.25 \\
\hline Salt & 0.25 \\
\hline Total & 100 \\
\hline Proximate & \\
\hline Crude protein & 16.50 \\
\hline Crude fibre & 2.50 \\
\hline Moisture & 5.00 \\
\hline Ash & 14.35 \\
\hline Ether extract & 12.5 \\
\hline Nitrogen free extract & 49.15 \\
\hline Vitmin and trace mineral & \\
\hline
\end{tabular}

Vitamin and trace mineral premix per kilogram of diet provided:

Vitamin A 10,000 IU; Vitamin D3 2,000 IU; Vitamin E ,20IU; Vitamin K3 2mg Vitamin B1 2mg; Vitamin B2 5mg; Vitamin B6 5mg; Vitamin B12 10mg; Niacin 30mg; Panthotenic acid 10mg; Folic acid 0.74mg; Zinc 25mg; Copper 10mg; Iron $120 \mathrm{mg}$; Manganese 60mg; Selenium 0.2mg.

Table 1: Percentage and proximate composition of the experimental diet.

\section{Moult period}

After acclimation, layers were randomly assigned to five treatment groups $\left(\mathrm{T}_{0}, \mathrm{~T}_{1}, \mathrm{~T}_{2}, \mathrm{~T}_{3}\right.$ and $\left.\mathrm{T}_{4}\right)$ with 40 hens, each divided into 4 replicate groups of 10 hens, following completely randomized design. The experimental layers of groups $\mathrm{T}_{0}$ were fed $120 \mathrm{~g}$ daily of the compounded layer diet, without additional $\mathrm{ZnO}$ (control group), whereas layers of groups $\mathrm{T}_{1}, \mathrm{~T}_{2}, \mathrm{~T}_{3}$ and $\mathrm{T}_{4}$ were fed additional $0.5 \%, 1.0 \%, 1.5 \%$ and $2.0 \% \mathrm{ZnO}$ supplementation per $\mathrm{kg}$ feed for 14 days. This was aimed at inducing moulting in the layers. Water was given ad libitum to the birds of all groups, and the lighting programme was 12L: 12D. During moult, individual body weights of the hens were monitored at day 0 (initial live body weight) and at day 14 (final live body weight). Feed intake was measured by weighing the leftover feed, less the original amount of feed offered to the birds. The number of days to cessation of lay of each group of birds was also recorded.

\section{Post moult}

At the end of 14 days moult period, layers of all groups were fed the compounded layers diets for 8 weeks period. At day 7 after the end of moult, 8 birds per treatment were randomly selected and humanely slaughtered, and the heart, lung, liver, gizzard, kidney and ovaries were excised and weighed, using an electronic weighing scale (Mettler Toledo). Organ weights were expressed as relative weight (\% of body weight). Post moult body weight of layers of each treatment groups was taken on day 14 post moult. Feed intake, feed conversion ratios (calculated on the basis of feed intake/g egg weight), and percentage hen-day production (Ratio of number of eggs produced to the number of layers times 100), were also determined.

\section{Statistical analysis}

All data were analyzed using the PROC ANOVA statement of SAS software [10]. Differences in mean of the parameters among treatment groups were compared at $5 \%$ level of significance $(\mathrm{P}<0.05)$, using Duncan's multiple range test.

\begin{tabular}{|c|c|c|c|c|c|c|}
\hline & & & Treatments & & & \\
\hline & $\mathrm{T}_{0}$ & $\mathrm{~T}_{1}$ & $\mathrm{~T}_{2}$ & $\mathrm{~T}_{3}$ & $\mathrm{~T}_{4}$ & Prob. \\
\hline \multicolumn{7}{|l|}{ Moult phase } \\
\hline \multicolumn{7}{|l|}{ Body weight (kg) } \\
\hline Day 0 & $1.79 \pm 0.05$ & $1.81 \pm 0.04$ & $1.82 \pm 0.04$ & $1.80 \pm 0.04$ & $1.75 \pm 0.03$ & $0.09^{\mathrm{NS}}$ \\
\hline Day 14 & $1.78 \pm 0.04^{a}$ & $1.70 \pm 0.03^{b}$ & $1.69 \pm 0.04^{b}$ & $1.59 \pm 0.03^{c}$ & $1.50 \pm 0.03^{c}$ & $0.00^{* *}$ \\
\hline Body weight loss (\%) & $0.56 \pm 0.06^{c}$ & $6.03 \pm 5.86^{b}$ & $7.17 \pm 5.72^{b}$ & $11.93 \pm 5.34^{\mathrm{ab}}$ & $14.81 \pm 9.38^{a}$ & $0.00^{* *}$ \\
\hline Feed intake (g) & $98.69 \pm 1.04^{a}$ & $77.29 \pm 1.68^{b}$ & $81.04 \pm 0.66^{b}$ & $72.64 \pm 0.96^{\mathrm{bc}}$ & $64.54 \pm 2.32^{c}$ & $0.00^{* *}$ \\
\hline Cessation of lay (day) & $0.00 \pm 0.00^{\mathrm{d}}$ & $9.29 \pm 0.74^{\text {a }}$ & $7.00 \pm 0.52^{\mathrm{b}}$ & $5.27 \pm 0.39^{c}$ & $5.12 \pm 6.51^{\mathrm{c}}$ & $0.00^{* *}$ \\
\hline \multicolumn{7}{|l|}{ Post moult } \\
\hline \multicolumn{7}{|l|}{ Body weight (kg) } \\
\hline Day 0 & $1.78 \pm 0.04$ & $1.70 \pm 0.03$ & $1.69 \pm 0.04$ & $1.59 \pm 0.03$ & $1.45 \pm 0.03$ & - \\
\hline Day 14 & $1.83 \pm 0.04$ & $1.89 \pm 0.04$ & $1.87 \pm 0.05$ & $1.83 \pm 0.02$ & $1.85 \pm 0.02$ & $0.16^{\mathrm{NS}}$ \\
\hline Body weight gain (\%) & $2.51 \pm 0.13^{d}$ & $10.04 \pm 0.02^{c}$ & $10.63 \pm 0.21^{c}$ & $15.07 \pm 0.14^{b}$ & $21.90^{\mathrm{a}} \pm 0.41^{\mathrm{a}}$ & $0.00^{* *}$ \\
\hline Feed intake (g/hen/day) & $101.54 \pm 2.10^{b}$ & $104.32 \pm 1.81^{\mathrm{ab}}$ & $107.28 \pm 1.98^{a}$ & $106.31 \pm 3.91^{a}$ & $108.81 \pm 2.63^{a}$ & $0.05^{*}$ \\
\hline FCR (g/g egg weight) & $1.69 \pm 0.03^{a}$ & $1.63 \pm 0.04^{\mathrm{ab}}$ & $1.54 \pm 0.03^{\mathrm{b}}$ & $1.55 \pm 0.02^{\mathrm{b}}$ & $1.60 \pm 0.04^{\mathrm{ab}}$ & $0.02^{*}$ \\
\hline Hen-day production (\%) & $60.60 \pm 4.08^{c}$ & $77.79 \pm 2.67^{b}$ & $83.58 \pm 1.07^{a}$ & $79.32 \pm 2.78^{\mathrm{ab}}$ & $80.92 \pm 4.23^{a}$ & $0.02^{*}$ \\
\hline Resumption of lay (days) & $0.00 \pm 0.00^{d}$ & $4.54 \pm 0.93^{c}$ & $6.61 \pm 1.21^{c}$ & $9.89 \pm 0.79^{b}$ & $16.71 \pm 1.13^{a}$ & $0.00^{* *}$ \\
\hline
\end{tabular}

a,b,c,d: means on the same row with different superscripts are significant at $5 \%$ or $1 \%$; NS: not significant; * $=P<0.05$;

** $P<0.01$; Prob-Probability.

Table 2: Effects of $\mathrm{ZnO}$ induced moult on performance of commercial layers. 
Citation: Machebe NS, Iweh P, Onyimonyi AE, Ekere OS, Abonyi F (2013) Zinc Oxide as an Effective Mineral for Induced Moulting: Effects on Post Moult Performance of Laying Hens in the Humid Tropics. J Veterinar Sci Technol S11: 003. doi:10.4172/2157-7579.S11-003

\section{Results}

Results of the effect of zinc induced moult of commercial laying hens on post moult performance are presented in table 2.

\section{Moulting period}

Induction of moulting with $\mathrm{ZnO}$ caused great $(\mathrm{P}<0.01)$ decline in the body weight, feed intake, and number of days to cessation of egg production in laying hens, compared to the non-moulted hens (control). Moulted birds in $\mathrm{T}_{4}$ showed greater $(\mathrm{P}<0.01)$ percentage loss in body weight $(15.41 \%)$, than those of moulted hens in $\mathrm{T}_{1}(6.03 \%)$ and $\mathrm{T}_{2}(7.17 \%)$. The percentage weight loss of moulted hens in $\mathrm{T}_{3}(11.93 \%)$ was intermediate among the treatments. Percentage body weight loss $(0.56 \%)$ of the non-moulted hens was very minimal and negligible. Feed consumption of the non-moulted hens was higher $(\mathrm{P}<0.01)$, compared to the moulted birds. A greater reduction in feed intake of the moulted hens was observed for hens in $\mathrm{T}_{4}(2.0 \% \mathrm{ZnO}$ supplementation). Feed intake declined progressively, as the amount of $\mathrm{ZnO}$ supplementation increased. Although, the non-moulted birds continued egg production throughout the duration of the experiment, highly significant $(\mathrm{P}<0.01)$ variations in the number of days to cessation of egg production was witnessed among the moulted groups of hens. Birds in $T_{3}$ and $T_{4}$ stopped egg production on day 5 after $\mathrm{ZnO}$ treatment, compared to those hens in $\mathrm{T}_{1}$ and $\mathrm{T}_{2}$ which ceased egg production on day 9 and day 7 , respectively.

\section{Post-moulting period}

Fourteen days after withdrawal of $\mathrm{ZnO}$ treatment, body weight of the moulted hens compared with the non-moulted hens were similar $(\mathrm{P}>0.05)$. Percentage gain in body weight of the hens in $\mathrm{T}_{4}(21.90 \%)$ during the same period was higher $(\mathrm{P}<0.05)$, than those of hens in other treatments. Moulted hens in $\mathrm{T}_{1}(10.04 \%)$ and $\mathrm{T}_{2}(10.63 \%)$ gained similar amount of body weight during post-moult, which differed greatly $(\mathrm{P}<0.01)$ from those of moulted hens in $\mathrm{T}_{3}(15.07 \%)$. Feed intake of moulted hens in $\mathrm{T}_{2}(107.28 \mathrm{~g} / \mathrm{hen} /$ day $), \mathrm{T}_{3}(106.31 \mathrm{~g} / \mathrm{hen} /$ day $)$ and $\mathrm{T}_{4}(108.81 \mathrm{~g} / \mathrm{hen} /$ day $)$ were found to be higher $(\mathrm{P}<0.05)$, compared to those of the non-moulted hens $\left(\mathrm{T}_{0}\right)$, during the post-moult period. However, feed consumption of hens in $\mathrm{T}_{0}(101.54 \mathrm{~g} / \mathrm{hen} /$ day $)$ and $\mathrm{T}_{1}$ $(104.32 \mathrm{~g} /$ hen/day) were similar $(\mathrm{P}<0.05)$ in the same period. Moulting of laying hen using $\mathrm{ZnO}$ caused a significant $(\mathrm{P}<0.05)$ decline in post- moult feed conversion ratio. Feed conversion ratio of hen in $\mathrm{T}_{2}$ ( $1.54 \mathrm{~g} / \mathrm{g}$ egg weight) and $\mathrm{T}_{3}(1.55 \mathrm{~g} / \mathrm{g}$ egg weight) were significantly $(\mathrm{P}<0.05)$ lower than those of the non-moulted hen $\left(\mathrm{T}_{0}, 1.69 \mathrm{~g} / \mathrm{g}\right.$ egg weight). No significant differences $(\mathrm{P}>0.05)$ in feed conversion ratio were observed for hens in $T_{1}(1.63 \mathrm{~g} / \mathrm{g}$ egg weight $)$ and $\mathrm{T}_{4}(1.60 \mathrm{~g} / \mathrm{g}$ egg weight). Percentage hen-day egg production differed $(\mathrm{P}<0.05)$ among the various treatment groups. Hen-day egg production of birds in $\mathrm{T}_{2}$ $(83.58 \%)$ and $\mathrm{T}_{4}(80.92 \%)$ were higher and differed $(\mathrm{P}<0.05)$ from those of hens in $\mathrm{T}_{0}(60.6 \%)$ and $\mathrm{T}_{1}(77.79 \%)$. Although, hen-day egg production of moulted hens in $\mathrm{T}_{3}(79.32 \%)$ compared well with other non-moulted hens $(\mathrm{P}>0.05)$, its value differed $(\mathrm{P}<0.05)$ from those of the non-moulted hens. The moulting method had a highly significant $(\mathrm{P}<0.01)$ effect on the length of time (days), it took the hens to return to egg production. Moulted hens in $\mathrm{T}_{4}$ resumed egg production much later (16.71 days), than those of other moulted hens $\left(\mathrm{T}_{1}, 4.54\right.$ days; $\mathrm{T}_{2}, 6.61$ days and $\mathrm{T}_{3}, 9.89$ days $)(\mathrm{P}<0.01)$. The number of days to resumption of egg production of moulted hens in $\mathrm{T}_{1}$ and $\mathrm{T}_{2}$ were comparable, but different $(\mathrm{P}<0.01)$ from the length of time, it took hens in $\mathrm{T}_{3}$ to resume egg production during the post-moulting period. The non-moulted hens $\left(\mathrm{T}_{0}\right)$ continued egg production throughout the duration of the experiment.

The results of the effects of $\mathrm{ZnO}$ supplementation on organ characteristics of moulted hens showed significant $(\mathrm{P}<0.05)$ variations among treatments in the relative weights of ovary, liver and kidney (Table 3 ). The relative weights of the ovary of hens in $\mathrm{T}_{3}(2.69 \%)$ and $\mathrm{T}_{4}(2.77 \%)$ were higher, and differed $(\mathrm{P}<0.05)$ from those of moulted hens in $\mathrm{T}_{2}$ (1.57\%). The relative weights of ovary of non-moulted hens $\left(\mathrm{T}_{0}, 1.95 \%\right)$ and moulted hens in $\mathrm{T}_{1}(1.86 \%)$ were similar $(\mathrm{P}>0.05)$. Highly significant $(\mathrm{P}<0.01)$ variation in the relative weight of kidney was found between the moulted and non-moulted hens. Moulted hens in $\mathrm{T}_{2}$ had higher $(\mathrm{P}<0.01)$ kidney weights than those in other treatments. Lower weight of kidney was observed in the non-moulted hens $\left(\mathrm{T}_{1}, 0.11 \%\right)$, and it differed $(\mathrm{P}<0.01)$ from the weight of kidney of hens in $\mathrm{T}_{4}(0.14 \%)$. Weight of kidney of hens in $\mathrm{T}_{1}$ and $\mathrm{T}_{3}(0.12 \%)$ were not different $(\mathrm{P}>0.05)$. The moulting treatments affected $(\mathrm{P}<0.05)$ the weight of the liver of the moulted hens. The relative weight of the liver was higher for hens in $\mathrm{T}_{2}$ $(3.16 \%)$ and differed $(\mathrm{P}<0.05)$ from those in all other treatments. Relative weight of liver of hens on $\mathrm{T}_{0}(2.35 \%), \mathrm{T}_{1}(2.40 \%), \mathrm{T}_{3}(2.04 \%)$ and $\mathrm{T}_{4}$ $(2.22 \%)$ were similar $(\mathrm{P}>0.05)$. Physical observation of the organs showed greenish colouration on the liver of hens in $\mathrm{T}_{3}$ and $\mathrm{T}_{4}$ (Figures 1-5). The greenish colouration was prominent on the liver of hens in $\mathrm{T}_{4}$.

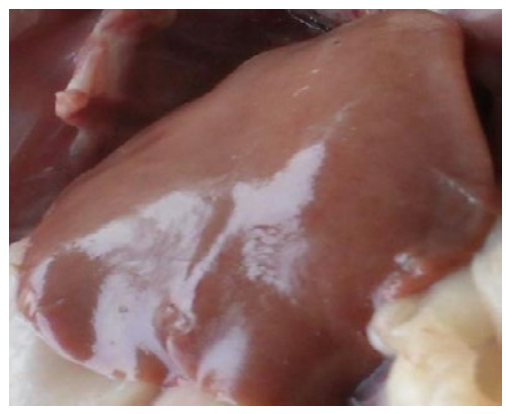

Figure 1: Liver of hens on $T_{0}$.

\begin{tabular}{|c|c|c|c|c|c|c|}
\hline & & & Treatments & & & \\
\hline Parameters (\%) & $\mathrm{T}_{0}$ & $\mathrm{~T}_{1}$ & $\mathrm{~T}_{2}$ & $\mathrm{~T}_{3}$ & $\mathrm{~T}_{4}$ & Prob. \\
\hline Live weight (kg) & $1.70 \pm 0.12$ & $1.83 \pm 0.17$ & $1.70 \pm 0.06$ & $1.65 \pm 0.08$ & $1.68 \pm 0.13$ & $0.88^{\mathrm{NS}}$ \\
\hline Ovary & $1.95 \pm 0.04^{\mathrm{ab}}$ & $1.86 \pm 0.27^{\mathrm{ab}}$ & $1.57 \pm 0.32^{b}$ & $2.69 \pm 0.27^{\mathrm{a}}$ & $2.77 \pm 0.50^{a}$ & $0.05^{*}$ \\
\hline Kidney & $0.10 \pm 0.00^{c}$ & $0.11 \pm 0.01^{\mathrm{bc}}$ & $0.19 \pm 0.01^{\mathrm{a}}$ & $0.12 \pm 0.01^{b c}$ & $0.14 \pm 0.12^{\mathrm{b}}$ & $0.00^{* *}$ \\
\hline Heart & $0.43 \pm 0.02$ & $0.42 . \pm 0.05$ & $0.44 \pm 0.01$ & $0.42 \pm 0.03$ & $0.42 \pm 0.00$ & $0.03^{\mathrm{NS}}$ \\
\hline Lung & $0.38 \pm 0.08$ & $0.41 \pm 0.03$ & $0.36 \pm 0.01$ & $0.45 \pm 0.04$ & $0.36 \pm 0.07$ & $0.67^{\mathrm{NS}}$ \\
\hline Liver & $2.35 \pm 0.10^{b}$ & $2.40 \pm 0.29^{b}$ & $3.16 \pm 0.05^{\mathrm{a}}$ & $2.04 \pm 0.14^{b}$ & $2.22 \pm 0.05^{b}$ & $0.00^{*}$ \\
\hline Gizzard & $2.84 \pm 0.02$ & $2.78 \pm 0.05$ & $2.59 \pm 0.01$ & $22.64 \pm 0.19$ & $2.71 \pm 0.16$ & $0.54^{\mathrm{NS}}$ \\
\hline
\end{tabular}

a,b: means on the same row with different superscripts are significant at $5 \%$ or $1 \%$

NS: not-significant; ${ }^{*}=\mathrm{P}<0.05 ;{ }^{* *} \mathrm{P}<0.01$; Prob.-Probability

Table 3: Effect of $\mathrm{ZnO}$ moult on organ characteristics of laying hens. 
Citation: Machebe NS, Iweh P, Onyimonyi AE, Ekere OS, Abonyi F (2013) Zinc Oxide as an Effective Mineral for Induced Moulting: Effects on Post Moult Performance of Laying Hens in the Humid Tropics. J Veterinar Sci Technol S11: 003. doi:10.4172/2157-7579.S11-003

Page 4 of 5

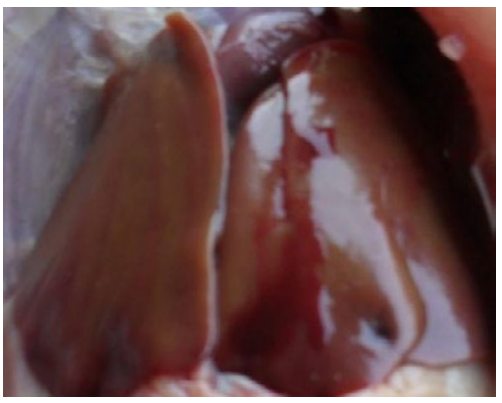

Figure 2: Liver of hens on $T_{1}$

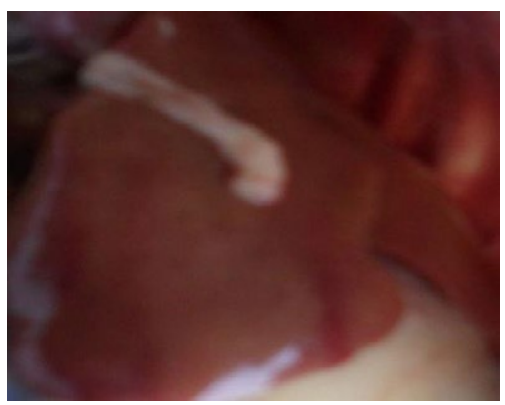

Figure 3: Liver of hens on $\mathrm{T}_{2}$.

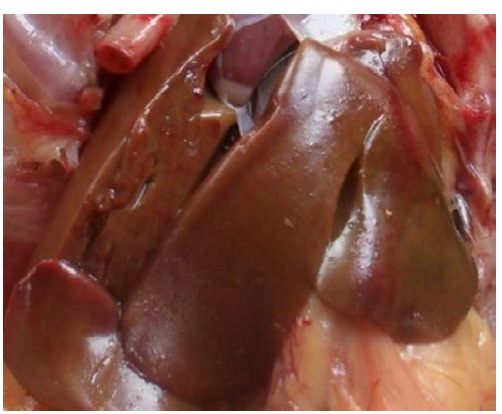

Figure 4: Liver of hens on $\mathrm{T}_{3}$

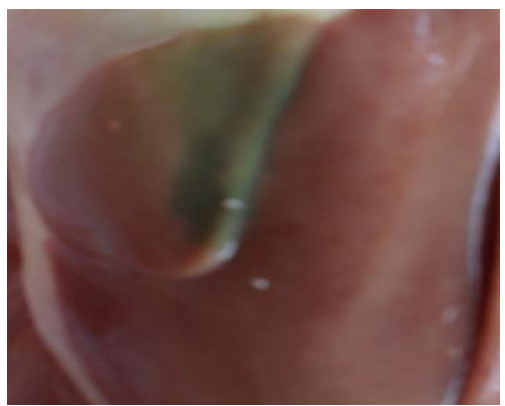

Figure 5: Liver of hens $T_{4}$

\section{Discussion}

The result of this study showed the effectiveness of using $\mathrm{ZnO}$ as a moulting agent in laying hens. Inducing moult in hens by the application of $\mathrm{ZnO}$ caused a significant decline in the body weight and feed intake of the birds. The rate of decline in these variables was dependent on the amount of $\mathrm{ZnO}$ salt used as moulting agent. For instance, moulted hens fed $2.0 \% \mathrm{ZnO}$ supplementation lost the greatest amount in body weight (15\%). Losses in body weight of about $25-30 \%$ have been reported in hens moulted using various amounts and types of zinc salt $[2,11]$. The decline in body weights in the moulted hens is not unconnected with decreases in feed consumption of the hens during the moulting process, and to the decrease in organ weights (especially the reproductive organs and liver), which occur simultaneously during with body weight loss during moulting [11,12]. Park et al. [12] reported about $65-70 \%$ reduction in feed intake in hens moulted using zinc salt (zinc acetate or zinc propionate). Incorporation of Zinc salts $(\mathrm{ZnO})$ in the diet of the hens above a certain amount is capable of decreasing the palatability of the diet, and has the potential of causing anorexia in the birds [13], thus, accounting for the decrease in feed intake in the moulted birds. Although the non-moulted hens continued egg production throughout the duration of the study, egg production by the moulted hens ceased few days after $\mathrm{ZnO}$ exposure, in accordance with the quantity of the salts added to the diets. This suggests that higher consumption of dietary $\mathrm{ZnO}$ increases the rate of reproductive quiescence in moulted hens. This result is in agreement with reports by Park et al. [12] and Johnson and Brake [14]. Reports by Johnson and Brake [14] indicated that zinc cation $\left(\mathrm{Zn}^{2+}\right)$ has the ability to induce follicular atresia and halting egg production. Therefore, using zinc as a moulting agent interferes with the physiological processes of reproduction in hens, probably by the inhibition of the hypothalamic-pituitary-gonadal axis. According to McDowell [15], zinc is physiologically involved in production, storage and secretion of sex hormones, and also affects the receptor sites of these hormones.

During post moulting period, significantly higher percentage body weight gain, feed intake, feed conversion ratio, and hen-day production was observed in the moulted hens, compared to the non-moulted hens. Higher gain in body weight in moulted hens during the recovery period may be ascribed to compensatory growth, as earlier mentioned. Reports by Summers [16] have shown that animals restricted in growth due to low nutrient intake, resulting from a low quality diet or environmental or disease stress, usually exhibit an increased rate of gain and enhanced feed utilization, when the stress(es) are eliminated. As evidenced in this study, it is probable that moulted hens consumed higher amount of the normal diet during post moult, to compensate for the loss in appetite that occurred during moulting. El-Gendi et al. [17] indicated an increase in feed consumption of birds during the first 4 to 6 weeks after moulting. Also, higher feed intake witnessed in the moulted hens during the same period suggests that feed intake of the hens returned to normal, irrespective of the quantity of dietary $\mathrm{ZnO}$ supplementation used in the study. The aim of a viable moulting programme is to enhance feed efficiency, and increase egg production and quality during birds moulted with $1.5 \%$ and $2.0 \% \mathrm{ZnO}$ supplementation. This greenish moult. Results showed that moulting hens with $\mathrm{ZnO}$ salt significantly decreased feed conversion ratio and increased egg production of the birds. This result agrees with reports by Durmus et al. [18], Salem et al [19], who observed improvement in egg production and feed efficiency in hens moulted using zinc salts. According to McDaniel and Aske [20], increase in egg production can relate to profit for the egg industry, depending on bird and feed prices and demand for egg. Increased egg production witnessed in the $\mathrm{Zn}$ treated birds may be attributed to the role of zinc in increasing blood plasma sex hormone concentration [18], and its interaction in metabolic processes in the animal like in protein synthesis, carbohydrate metabolism, reproduction, enzyme activation and growth [21]. In addition, increased post moult egg production in 
Citation: Machebe NS, Iweh P, Onyimonyi AE, Ekere OS, Abonyi F (2013) Zinc Oxide as an Effective Mineral for Induced Moulting: Effects on Post Moult Performance of Laying Hens in the Humid Tropics. J Veterinar Sci Technol S11: 003. doi:10.4172/2157-7579.S11-003

Page 5 of 5

moulted hens may be accounted for by the decline in the production of shell-less egg during the same period [12]. In consonance with reports by Khan et al. [8] and Khan et al. [11], that moulted hens that lost higher percentage in body weight exhibited greatest improvement in post moult egg production, our study showed that moulted hens fed $1.0 \%, 1.5 \%$ and $2.0 \% \mathrm{ZnO}$ supplementation which lost higher amount in body weight, had maximum egg production during post moult. In the moulted hens, post moult resumption of egg production increased progressively as the amount of dietary $\mathrm{ZnO}$ supplementation increased across treatment. Birds exposed to higher amount of dietary $\mathrm{ZnO}$ resumed egg production much later, compared with those exposed to lower amount of $\mathrm{Zn}$ mineral, implying that higher consumption of dietary $\mathrm{Zn}$ by laying hens, effectively increases the rate of involution of their reproductive organs. This agrees with the findings of Berry [2] that hens return to egg production in proportion to the amount of $\mathrm{Zn}$ added to their diet and the duration of dietary exposure.

Results of these studies showed that inducing moult in hens using $\mathrm{ZnO}$ had a profound effect on the relative weights of the ovary, liver and gizzard of the birds. Our findings revealed an increase in the weight of these organs in moulted birds, in contrast to the non-moulted hens Reports by Park et al. [12], Khan et al. [11] revealed that the moulting process causes a decrease in the weights of the ovary, and liver, especially during the moulting period. During the recovery period (post moulting period), when the moulting agent $(\mathrm{ZnO})$ has been withdrawn, the rate of growth of these organs may have increased to compensate for decrease in their growth caused by the moulting process. This may account for the increased growth of these organs, as observed in our study, in contrast to the findings of Park et al. [12], Khan et al. [11], that moulting process caused a significant decline in the relative weights of the ovary and liver. It may be inferred that increase in the weight of the liver of moulted hens during the recovery period was because of the re-instatement of liver energy resources like glycogen and lipids, and estrogen-dependent egg component synthesis, which were lost during the moulting period [12]. Also, the liver may have been actively involved in the process of detoxification of the excess $\mathrm{Zn}$ mineral used in inducing moult. A greenish colouration was observed on the liver of birds moulted with $1.5 \%$ and $2.0 \% \mathrm{ZnO}$ supplementation. This greenish colouration was very prominent in the latter birds. The cause of this colour change in the liver of these birds is unclear. However, it may be suggested that it was caused by an increased bile accumulation in the liver, as a result of the high dietary $\mathrm{Zn}$ mineral intake by the birds. The increase in the weight of kidney in the moulted hens may be credited to the increased physiological functions of the kidney in processing and removing metabolic waste and excess ions (detoxified $\mathrm{ZnO}$ ) from the blood, and by so doing, regulating the acid-base or electrolyte balance in the body of the birds [22]. The amount of dietary $\mathrm{ZnO}$ used for moulting of the hens had no adverse effect on the relative weights of heart, lungs, and gizzards.

In conclusion, these results demonstrate that in order to achieve good post moult performance of laying hens in the humid tropics, farmers should practice the use of $1.0 \% \mathrm{ZnO}$ supplementation per $\mathrm{kg}$ diet, as an effective method to achieve induced moulting because higher percentage inclusion levels of $\mathrm{ZnO}$ may be detrimental to the overall physiology of the birds.

\section{Acknowledgements}

The authors are grateful to Mr. Samuel Chime, the Farm Manager, and all the Technical Staff of the Poultry Unit, Department of Animal Science, Teaching and Research farm, University of Nigeria, Nsukka, for their immense contributions towards the successful completion of this research work.

\section{References}

1. North MO, Bell DD (1990) Commercial chicken production manual. ( $4^{\text {th }}$ edn) Van Nostrand Reinhold.

2. Berry WD (2003) The physiology of induced moulting. Poult Sci 82: 971-980.

3. Gast RK, Ricke SC (2003) Current and future prospects for induced moulting in stress in chickens. Avian Dis 27: 972- 979

4. Holt PS (2003) Moulting and Salmonella enterica serovar enteritidis infection the problem and some solutions. Poult Sci 82: 1008-1010.

5. Keshavarz K, Quimby FW (2002) An investigation of different moulting techniques with an emphasis on animal welfare. J Appl Poult Res 11: 54-67.

6. Webster $A B$ (2003) Physiology and behavior of the hen during induced moult. Poult Sci 82: 992-1002.

7. Bell DD (2003) Historical and current moulting practices in the U.S. table egg industry. Poult Sci 82: 965-970.

8. Khan RU, Nikousefat Z, Javdani M, Tufarelli V, Laudadio V (2011) Zinc-induced moulting: production and physiology. Worlds Poult Sci J 67: 497-506.

9. Brown KH, Rivera JA, Bhutta Z, Gibson RS, King JC, et al. (2004) Internationa Zinc Nutrition Consultative Group (IZiNCG) technical document \#1. Assessment of the risk of zinc deficiency in populations and options for its control. Food Nutr Bull 25: S99-S203.

10. Stokes M, Curtis N (2001) Statistical Enhancements in Release 6.12 of the SASa System. SAS STAT Users Guide, SAS. Inst Inc., Cary, NC.

11. Khan SH, Rehman A, Jehanzeb A (2011) Effects of dietary minerals on postmoult performance of laying hens. Vet World 4: 386-395.

12. Park SY, Birkhold SG, Kubena LF, Nisbet DJ, Ricke SC (2004) Effects of high zinc diets using zinc propionate on moult induction, organs, and postmoult egg production and quality in laying hens. Poult Sci 83: 24-33.

13. Kim WK, Patterson PH (2005) Effects of dietary zinc supplementation on hen performance, ammonia volatilization, and nitrogen retention in manure. $J$ Environ Sci Health B 40: 675-686.

14. Johnson AL, Brake J (1992) Zinc-induced moult: evidence for a direct inhibitory effect on granulosa cell steroidogenesis. Poult Sci 71: 161-167.

15. McDowell LR (1992) Minerals in Animal and Human Nutrition: Comparative Aspects to Human Nutrition. ( $2^{\text {nd }}$ Edn), Academic Press, Inc., San Diego, USA.

16. Summers JD (2008) Compensatory growth. Technical Information bulletin 3 o the Canadian Poultry Industry Council, The Poultry Site.

17. El-Gendi GM, Samak HR, Mohamed AA (2009) Effect of induced moulting on some productive and physiological traits in Hy-Line hens. Egyptian Poultry Science Journal 29: 385-405.

18. Durmus I, Atasoglu C, Mizrak C, Ertas S, Kaya M (2004) Effect of increasing zinc concentration in the diets of brown parent stock layers on various production and hatchability rates. Arch Tierz Dummerstorf 47: 483-489.

19. Salem AA, Eman M, Nofal ME (2005) Productive and physiological performance of local laying hens as affected by force moulting methods. Egypt Journal of Applied Science 20: 12-31.

20. McDaniel BA, Aske DR (2000) Egg prices, feed costs, and the decision to moult. Poult Sci 79: 1242-1245.

21. Underwood EJ, Suttle NF (1999) The mineral nutrition of livestock. ( $3^{\text {rd }}$ Edn) CABI Publishing, London, UK.

22. Banday MT, Bhakt M, Hamid SA (2009) Avian Gout: Causes Treatment and Prevention. 